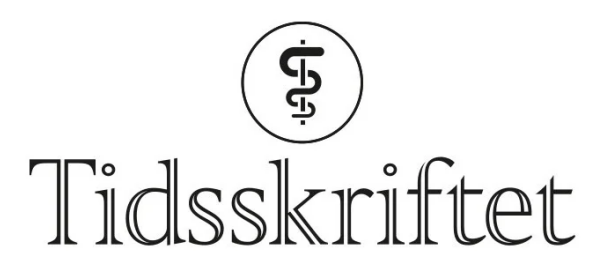

DEN NORSKE LEGEFORENING

\title{
Natrium bør måles med blodgassapparat ved forstyrrelser i protein- eller lipidnivået
}

FRA LABORATORIET

\section{GAUTE HANSEN}

gaute.lund.hansen@helse-bergen.no

Gaute Hansen er lege i spesialisering i medisinsk biokjemi ved Avdeling for medisinsk biokjemi og farmakologi ved Haukeland universitetssjukehus.

Forfatteren har fylt ut ICMJE-skjemaet og oppgir ingen interessekonflikter.

\section{Elektrolytter måles både på laboratoriet og med blodgassapparat på sykehusavdelingene. Ofte benyttes begge metoder om hverandre hos samme pasient. Metodeforskjeller gjør imidlertid at svarene ikke alltid er sammenlignbare.}

Plasma består normalt av ca. 93 \% væske og 7 \% proteiner og lipider. Når natriumkonsentrasjon måles på laboratoriet, fortynnes prøven, og målemetoden forutsetter da at væskefasen i prøven er ca. 93 \%. Når natrium måles med blodgassapparat, gjøres det i ufortynnet prøve. Mens blodgassapparatet gir korrekt natriumkonsentrasjon uavhengig av størrelsen på væskefasen, vil natrium i serum eller plasma som er analysert fortynnet, kunne variere med endringer i pasientens protein- eller lipidnivå, og dermed endringer i størrelsen på væskefasen. Analysert i fortynnet prøve kan natriumkonsentrasjonen i serum og plasma bli falskt lav hos pasienter som har et $\emptyset \mathrm{kt}$ protein- eller lipidnivå, og falskt høy hos pasienter som har et redusert protein- eller lipidnivå.

Hyperproteinemi eller -lipidemi kan forekomme ved bl.a. diabetisk ketoacidose, pankreatitt, obstruktiv ikterus og myelomatose (1). Hos kritisk syke kan hypoalbuminemi oppstå via ulike mekanismer, som endring i produksjon og nedbrytning av albumin, og lekkasje ut i det ekstravaskulære rom ved systemisk inflammatorisk respons (므). På en nyfødtintensivavdeling i New Zealand hadde $58 \%$ av pasientene hypoalbuminemi. Det var signifikant forskjell mellom natriumkonsentrasjon målt med blodgassapparat og på laboratoriet, der laboratoriet målte for høy konsentrasjon, og diskrepansen mellom metodene økte jo lavere albuminkonsentrasjonen var (3).

\section{Eksempel: pasient med normale protein- og lipidverdier}


Konsentrasjonen av natrium måles med ioneselektiv elektrode(ISE). Det benyttes en elektrode med en membran som er spesifikk for natrium, slik at andre typer ioner i prøven ikke interfererer med målingen.

\section{Kasuistikk}

Hos en pasient med myelomatose ble det utført måling av elektrolytter i serum. Denne viste natrium $148 \mathrm{mmol} / \mathrm{L}$ (referanseområde 137-145). Det ble imidlertid også utført en blodgassanalyse på avdelingen, som viste natrium $158 \mathrm{mmol} / \mathrm{L}$. Man vurderte det slik at blodgassapparatet ikke fungerte, og at pasienten således hadde lett forhøyet natriumkonsentrasjon. Det ble gitt beskjed til preanalytisk seksjon om problemet med blodgassapparatet. Diskrepansen mellom målingene skyldtes imidlertid ikke feil ved blodgassapparatet, men var å forvente som en indirekte konsekvens av pasientens grunnsykdom, da det var betydelig økt konsentrasjon av totalprotein på 110 g/L (62-78).

Plasma består som nevnt normalt av ca. 93\% væske og 7 \% lipider og proteiner. Natrium finnes nesten utelukkende i væskefasen. Vi tenker oss en plasmaprøve med natriumkonsentrasjon på $150 \mathrm{mmol} / \mathrm{L}$ i vceskefasen og at væskefasen utgjør $93 \% \mathrm{av}$ prøvevolumet. Når prøven analyseres på laboratoriet, måles konsentrasjon i væskefasen, men prøven fortynnes før den analyseres på instrumentet (såkalt indirekte ISE-måling), f.eks. 1 del prøve per zo deler fortynningsløsning. Regnestykket blir: [(mengden natrium i prøven) / (væskevolumet i prøven + volum av fortynningsløsning)] $\times$ fortynningsfaktoren (Fortynningen er egentlig tatt høyde for under kalibreringen, men dette kan tilnærmes ved at målt verdi ganges opp med en fortynningsfaktor.)

For aktuelle prøve: $[(150 \mathrm{mmol} / \mathrm{L} \times 0,93) /(0,93+30)] \times 31=140 \mathrm{mmol} / \mathrm{L}$

Når prøven analyseres med blodgassapparat, måles konsentrasjon i ufortynnet væskefase (såkalt direkte ISE-måling). Blodgassinstrumentet vil dermed måle $150 \mathrm{mmol} / \mathrm{L}$. Konvensjonen er imidlertid at målt verdi ganges med o,93((4), s. 607-8), slik at svaret vil gis ut som $140 \mathrm{mmol} / \mathrm{L}$, og de to metodene er samstemte i dette tilfellet. (I tillegg er det kalibrert/ganget med en faktor som skal kompensere for forskjell i aktivitetskoeffisient.) Referanseområdene er også basert på konsentrasjonen i normalt serum eller plasma, og ikke konsentrasjonen i væskefasen direkte. Imidlertid er det natriumkonsentrasjonen i væskefasen som egentlig er fysiologisk relevant.

\section{Eksempel: pasient med høye proteinverdier}

La oss tenke oss en plasmaprøve som også denne gangen har natriumkonsentrasjon på $150 \mathrm{mmol} / \mathrm{L}$ i vceskefasen. Men nå har pasienten høye proteinverdier, og væskefraksjonen i plasma utgjør bare $87 \%$.

Ved måling på laboratoriet blir regnestykket $[(150 \mathrm{mmol} / \mathrm{L} \times 0,87) /(0,87+30)] \times$ $31=131 \mathrm{mmol} / \mathrm{L}$, altså falsk hyponatremi ("pseudohyponatremi»).

Blodgassapparatet vil igjen vise $140 \mathrm{mmol} / \mathrm{L}$, som beskrevet over. Merk at blodgassapparatet gir korrekt natriumkonsentrasjon i begge tilfellene, uavhengig av størrelsen på væskefasen.

\section{Konklusjon}

Vi anbefaler at natriumkonsentrasjon hos kritisk syke pasienter og andre pasienter hvor man mistenker betydelige avvik i protein- eller lipidverdier, kun måles med blodgassapparat. 


\section{LITTERATUR}

1. Hoorn EJ, Sterns RH. Causes of hyponatremia without hypotonicity (including pseudohyponatremia). UpToDate. https://www.uptodate.com/contents/causes-of-hyponatremiawithout-hypotonicity-including-pseudohyponatremia Lest 15.7.2021.

2. Gounden V, Vashisht R, Jialal I. Hypoalbuminemia. Treasure Island, FL: StatPearls Publishing, 2021. https://www.ncbi.nlm.nih.gov/books/NBK52608o/ Lest 15.7.2021.

3. King RI, Mackay RJ, Florkowski CM et al. Electrolytes in sick neonates - which sodium is the right answer? Arch Dis Child Fetal Neonatal Ed 2013; 98: F74-6. [PubMed][CrossRef]

4. Nader R, Horvath AR, Wittwer CT. Tietz textbook of clinical chemistry and molecular diagnostics. 6. utg. St. Louis, MO: Elsevier, 2018.

Publisert: 27. september 2021. Tidsskr Nor Legeforen. DOI: 10.4045/tidsskr.21.0558

(C) Tidsskrift for Den norske legeforening 2023. Lastet ned fra tidsskriftet.no 26. april 2023. 